\title{
Kedisiplinan Aparatur Sipil Negara pada Kantor Badan Kependudukan dan Keluarga Berencana Nasional Provinsi Sulawesi Selatan
}

\author{
Jamaluddin$^{1}$, M. Said Saggaf ${ }^{2}$, Sri Rahayu ${ }^{1}$ \\ ${ }^{1}$ Universitas Negeri Makassar \\ ${ }^{2}$ STIA Prima, Sengkang
}

\begin{abstract}
ABSTRAK
Penelitian ini bertujuan untuk mengetahui Kedisiplinan Aparatur sipil Negara pada kantor Badan Kependudukan Dan Keluarga Berencana Nasional Provinsi Sulawesi Selatan. Penelitian ini menggunakan pendekatan kuantitatf dengan populasi sebanyak 108 dan sampel sebanyak 25 persen dari jumlah populasi sehingga populasi diperoleh 29 sampel. Dari 29 sampel tersebut 26 diantaranya dijadikan sebagai responden dan 3 dijadikan sebagai informan. Pengumpulan data dengan teknik observasi, angket, wawancara dan dokumentasi, sedangkan teknik analisis data yang digunakan yaitu analisis persentase. Hasil penelitian ini menunjukkan bahwa kedisiplinan Aparatur Sipil Negara pada kantor Badan kependudukan dan keluarga Berencana Nasional Provinsi sulawesi selatan berada pada kategori cukup baik. Ditinjau dari disiplin waktu, disiplin dalam berpakaian, menggunakan perlengkapan kantor dengan hati-hati, menghasilkan jumlah dan kualitas yang memuaskan, mengikuti cara kerja yang ditentukan dan menyelesaikan pekerjaan dengan penuh semangat.
\end{abstract}

Kata kunci: Disiplin, ASN

ABSTRACT

This study aims to determine the discipline of State civil apparatus at the office of the National Population and Family Planning Agency of South Sulawesi Province. This study uses quantitative approach with population of 108 and sample as much 25 percent of the total population so that the population obtained 29 samples. Of the 29 samples 26 of them were made as respondents and 3 were made as informants. Data collection with observation techniques, questionnaires, interviews and documentation, while data analysis techniques used are percentage analysis. The results of this study indicate that the discipline of the State Civil Apparatus at the office of the Population and Family Planning Agency of South Sulawesi Province is in the category quite well. Judging from the discipline of time, discipline in dressing, using office supplies with care, generating satisfactory amounts and qualities, following determined work and completing a full-time job.

Keywords: Discipline, ASN

\section{PENDAHULUAN}

Suatu Organisasi baik organisasi Pemerintah maupun swasta dibentuk untuk mencapai tujuan, dan untuk mencapai tujuan tersebut diperlukan faktor-faktor yang dapat mendukung pencapaian tujuan organisasi berupa sumber daya manusia, material, alat-alat penunjang 
kegiatan (Anantanyu, 2011; Barata, 2003; Fuad, 2000). Dalam pencapaian tujuan diperlukan adanya unsur aparatur negara dalam melaksanakan tugasnya, baik sebagai abdi negara maupun abdi masyarakat. Jika ditinjau dari segi ilmu administrasi, aparatur negara merupakan aspek administrasi yang diperlukan dalam penyelenggaraan pemerintahan yakni untuk mencapai tujuan nasional. Aspek administrasi itu dapat berupa kelembagaan (organisasi) dan dapat pula manusia yang disebut pegawai (Hariandja, 2002; Nuryanta, 2008).

Peranan Sumber daya Manusia adalah salah satu faktor penting dalam organisasi, Pemanfaatan Sumber daya Manusia secara efektif adalah jalan bagi organisasi untuk mempertahankan kelangsungan hidup dan pertumbuhan Instansi Pemerintah kedepannya (Angkasa, 2011; Martauli, 2016; Setiarini, 2016). Dengan kata lain, keberhasilan atau kemunduran suatu organisasi bergantung pada kedisiplinan, keahlian dan keterampilan pegawai. ASN merupakan Sumber Daya Manusia yang bertugas memberikan pelayanan kepada masyarakat secara profesional, jujur, adil dan merata dalam penyelenggaraan tugas negara sesuai kedudukan mereka masing-masing, tugas dan fungsinya mereka sebagai unsur aparatur negara (Undang-Undang Republik Indonesia Nomor 5 tahun 2014 tentang ASN). Pelaksanaan pelayanan dalam suatu organisasi adalah penting dan menentukan dalam mencapai tujuan negara. Baiknya suatu pelayanan terhadap masyarakat akan mendorong masyarakat untuk berpartisipasi dalam proses pembangunan (Surbakti, 1992; Tangkilisan, 2005).

Era reformasi disadari bahwa tugas pegawai negeri selaku pelayan masyarakat, motivator dan fasilitator pembangunan semakin berat Untuk itu, diperlukan pegawai negeri yang mampu menghadapi serta mengantisipasi segala tantangan dan memiliki tingkat kedisiplinan yang tinggi (Iskandar, 2017). Disiplin pegawai berangkat dari pandangan bahwa tidak ada manusia yang sempurna dari kehilafan dan kesalahan (Romli, 2008). Oleh, karena itu, setiap organisasi atau Instansi perlu memiliki berbagai ketentuan yang harus taat pegawaianya yakni standar yang harus dipenuhi.

Upaya yang dilakukan agar ASN dapat melaksanakan segala tugas dan fungsinya serta bertanggung jawab dan profesional sebagaimana yang diharapkan, maka perlu dilaksanakan pembinaan kedisiplinan, baik melalui pendidikan dan pelatihan maupun pemberian keteladanan dari pimpinan (Darmayanti, 2016). Kedisiplinan merupakan kata kunci dalam keberhasilan dan efektivitas pelaksanaan tugas secara berdaya guna dan berhasil guna. Badan Kependudukan Dan Keluarga Berencana Nasional merupakan salah satu instansi pemerintah yang berperan besar memberikan pelayanan dan mensosialisasikan kepada masyarakat mengenai program-program KB (keluarga berencana) dan keluarga sejahtera. Oleh karena itu, keberhasilan BKKBN tidak terlepas dari kedisiplinan personel intansi tersebut dalam melaksanakan job-job kerja dan aturan yang ada. Oleh karena itu, setiap pegawai dituntut kedisiplinannya yang tinggi dalam melaksanakan semua peraturan yang berlaku dalam kedudukannya sebagai ASN dan aturanaturan yang berlaku secara intern dalam instansi.

Kedisiplinan yang menjadi kajian ini adalah kedisiplinan yang mencakup berbagai aspek, yaitu: disiplin waktu, disiplin dalam berpakaian, menggunakan perlengkapan kantor dengan hati-hati, menghasilkan jumlah dan kualitas pekerjaan yang memuaskan, mengikuti cara kerja yang ditentukan, dan menyelesaikan pekerjaan dengan penuh semangat (Hidayat \& Taufiq, 2012). Setiap pegawai dalam lingkup Badan Kependudukan dan Keluarga Berencana provinsi 
Jamaluddin, Said Saggaf, Sri Rahayu, Kedisiplinan Aparatur Sipil Negara pada Kantor Badan Kependudukan dan Keluarga Berencana Nasional Provinsi Sulawesi Selatan $\mid 27$

sulawesi selatan harus menunjukkan sikap disiplin dalam melaksanakan tugas dalam kedudukannya sebagai ASN.

Berbagai sikap atau perilaku yang ditunjukkan pegawai merupakan gambaran kedisiplinan pegawai yang seharusnya mendapatkan perhatian, pengawasan sekaligus pembinaan dari pimpinan agar pegawai dapat menunjukkan kedisiplinan yang tinggi dalam peningkatan kinerjanya (Abdullah, 2014; Sahertian, 2011). Aspek kedisiplinan merupakan salah satu faktor yang dapat menentukan kinerja pegawai di kantor manapun. Berdasarkan hasil observasi awal pada tanggal 16 Januari s/d sampai 24 januari 2017, peneliti menemukan masalah seperti masih adanya beberapa pegawai yang datang pada pukul $08.30 \mathrm{Wita}$, padahal masuk jam kerja pada pukul 07.30 Wita, adanya pegawai yang kadang tidak memakai kartu pengenal/identitas di dalam kantor, dan ada juga pegawai yang pulang kantor bukan pada waktunya, dan masih ada saja pegawai yang tidak memakai seragam sesuai ketentuan organisasi.

\section{METODE PENELITIAN}

Desain penelitian ini adalah penelitian deskriptif kuantitatif. Untuk mendeskripsikan kedisiplinan pegawai, juga mendeskripsikan upaya peningkatan kedisiplinan ASN pada kantor Badan Kependudukan dan Keluarga Berencana Nasional Provinsi Sulawesi Selatan. Adapun Populasi penelitian ini berjumlah 108 orang. Sedangkan sampel penelitian yang diambil berjumlah 29 responden. Untuk memperoleh data yang dibutuhkan dalam penelitian ini, maka digunakan teknik observasi, angket, wawancara, dan dokumentasi. Teknik analisis data yang digunakan yaitu secara deskriptif dengan cara mempersentasikan setiap item yang terdapat pada angket pertanyaan.

\section{HASIL PENELITIAN PEMBAHASAN}

Kedisiplinan merupakan suatu keadaan atau suasana yang tercipta dengan tertib dan teratur, di mana orang-orang yang berada dalam suatu organisasi atau instansi tunduk, patuh dan taat terhadap peraturan yang berlaku baik secara tertulis maupun lisan. selaku ASN, maka sudah sepatutnya harus dapat melaksanakan tugas dengan penuh disiplin. Kedisiplinan pegawai yang ditunjukkan melalui perilakunya dalam sehari-hari di kantor, banyak indikator yang dapat dilihat dalam rangka pengukuran tingkat kedisiplinannya, seperti: disiplin waktu, disiplin dalam berpakaian, menggunakan perlengkapan kantor dengan hati-hati, menghasilkan jumlah dan kualitas yang memuaskan, menyelesaikan pekerjaan dengan penuh semangat dan mengikuti cara kerja yang telah ditentukan. Setelah hasil data penelitian disajikan, maka diketahui bahwa kedisiplinan Aparatur Sipil Negara pada kantor Badan Kependudukan dan Keluarga Berencana Nasional tergolong baik. Kedisiplinan ASN pada Kantor BKKBN Provinsi Sulawesi Selatan dapat diketahui berdasarkan aspek:

1. Penerapan disiplin waktu pegawai berada pada kategori cukup baik. Hal ini dapat dibuktikan dengan hasil penelitian bahwa pegawai sudah menerapkan disiplin jam masuk kantor dengan semestinya. 
2. Penerapan disiplin berpakaian pegawai berada pada kategori baik. Hal ini menunjukkan bahwa pegawai di kantor telah menerapkan aturan organisasi tersebut

3. Menggunakan perlengkapan kantor dengan hati-hati pegawai berada pada kategori baik. Hal ini menunjukkan bahwa pegawai telah menggunakan perlengkapan kantor dengan baik sesuai ketentuan, karna perlengkapan kantor di BKKBN memiliki berita acara dan masing-masing pegawai mempunyai tanggungjawab tersebut.

4. Menghasilkan jumlah dan kualitas pekerjaan yang memuaskan pegawai berada pada kategori baik

5. Mengikuti cara kerja yang telah ditentukan berada pada kategori cukup baik. Hal ini dapat dilihat dari hasil pengelolahan angket.

6. Menyelesaikan pekerjaan dengan penuh semangat pegawai berada pada kategori kurang baik. Hal ini dapat dilihat dari hasil wawancara kepala sub kepegawaian bahwa beberapa pegawai menyelesaikan pekerjaannya kadang tidak tepat waktu, jika untuk menyelesaikan pekerjaannya diberi batas waktu ppada pukul 10.00 wita, mereka baru menyelesaikannya pada pukul 12.00 wita.

Sikap ketaatan atau kepatuhan pegawai dalam melaksanakan pekerjaan atau aturan yang berlaku ditinjau dari indikator: disiplin waktu, disiplin dalam berpakaian, menggunakan perlengkapan kantor dengan hati-hati, menghasilkan jumlah dan kualitas yang memuaskan, menyelesaikan pekerjaan dengan penuh semangat dan mengikuti cara kerja yang telah ditentukan mempunyai pengaruh penting terhadap disiplin pegawai di kantor BKKBN Provinsi Sulawaesi Selatan. Sebagaimana yang telah dikemukakan oleh Leteiner pada dasarnya faktorfaktor tersebut turut membentuk kedisiplinan pegawai di dalam suatu organisasi. Hasil penelitian mengenai kedisiplinan Aparatur Sipil negara pada kantor Badan Kependudukan dan Keluarga Berencana Provinsi Sulawesi Selatan berada pada kategori cukup baik.

\section{SIMPULAN}

Berdasarkan hasil penelitian dan pembahasan yang telah diuraikan mengenai Kedisiplinan Aparatur Sipil Negara pada kantor Badan Kependudukan dan Keluarga Berencana Nasional Provinsi sulawesi Selatan berada pada kategori cukup baik, hal ini membuktikan bahwa pegawai BKKBN telah menunjukkan sikap ketaatan atau kepatuhan dalam melaksanakan pekerjaan atau aturan yang berlaku, dengan indikator kedisplinan waktu, kedisiplinan dalam berpakaian, menggunakan perlengkapan kantor dengan hati-hati, menghasilkan jumlah dan kualitas yang memuaskan, menyelesaikan pekerjaan dengan penuh semangat dan mengikuti cara kerja yang telah ditentukan.

\section{DAFTAR PUSTAKA}

Abdullah, M. (2014). Manajemen dan evaluasi kinerja karyawan. Aswaja Pressindo.

Anantanyu, S. (2011). Kelembagaan Petani; Peran dan Strategi Pengembangan Kapasitasnya. 
Jamaluddin, Said Saggaf, Sri Rahayu, Kedisiplinan Aparatur Sipil Negara pada Kantor Badan

Kependudukan dan Keluarga Berencana Nasional Provinsi Sulawesi Selatan $\mid 29$

Jurnal Sosial Ekonomi Pertanian Dan Agribisnis, 7(2), 102-109.

Angkasa, W. I. (2011). Strategi dan Kelayakan Pengembangan Lembaga Intermediasi untuk Meningkatkan Daya Saing Usaha Kecil dan Menengah di Indonesia (Studi Kasus Balai Inkubator Teknologi di Puspiptek Serpong).

Barata, A. A. (2003). Dasar-dasar pelayanan prima. Elex Media Komputindo.

Darmayanti, E. (2016). Analisis Faktor-Faktor Penentu Disiplin Kerja Aparatur Sipil Negara Di Kabupaten Nunukan. Universitas Terbuka.

Fuad, M. (2000). Pengantar Bisnis. Gramedia Pustaka Utama.

Hariandja, M. T. E. (2002). Manajemen sumber daya manusia. Grasindo.

Hidayat, Z., \& Taufiq, M. (2012). Pengaruh Lingkungan Kerja dan Disiplin Kerja serta Motivasi Kerja Terhadap Kinerja Karyawan Perusahaan Daerah Air Minum (PDAM) Kabupaten Lumajang. WIGA-Jurnal Penelitian Ilmu Ekonomi, 2(1).

Iskandar, D. J. (2017). Menilik Kembali Makna Reformasi Birokrasi Publik Dalam Konteks Aktualisasi Semangat Pelayanan Publik Prima. Jurnal Ilmu Politik Dan Komunikasi, 5(1).

Martauli, E. D. (2016). Faktor-Faktor Yang Mempengaruhi Kinerja Usaha Wanita Wirausaha Kerupuk Udang Di Provinsi Jambi. IPB (Bogor Agricultural University).

Nuryanta, N. (2008). Pengelolaan Sumber Daya Manusia (Tinjauan Aspek Rekrutmen dan Seleksi). EL TARBAWI, 1(1), 55-69.

Romli, L. (2008). Masalah Reformasi Birokrasi. Jurnal Kebijakan Dan Manajemen PNS, 50, $1-$ 3.

Sahertian, P. (2011). Perilaku Kepemimpinan Berorientasi Hubungan Dan Tugas Sebagai Anteseden Komitmen Organisasional, Self-Efficacy Dan Organizational Citizenship Behavior (OCB). Jurnal Manajemen Dan Kewirausahaan, 12(2), pp-156.

Setiarini, O. W. (2016). Pengaruh pertumbuhan ekonomi terhadap infant mortality dan implikasi kebijakan pemerintahan di negara ASEAN. Universitas Jember.

Surbakti, R. (1992). Memahami ilmu politik. Grasindo.

Tangkilisan, H. N. S. (2005). Manajemen publik. Grasindo. 